\title{
Women in U.S. Construction Management Positions: A Qualitative Look at Motivations, Challenges and Considerations
}

\author{
Scott W. Kramer, Stephanie Woods and April E. Simons
}

Auburn University, Auburn, Alabama, USA

\begin{abstract}
This research study considered why there are relatively so few women working in the United States construction management industry. The qualitative study examined the social and economic factors that influence women's career opportunities and choices, identified ways to interest girls and women in construction management, and determined how employers can better support women already working as construction managers. Five women who either are currently working in U.S. construction management positions, or who have worked in construction management, were interviewed using a qualitative research design. These structured-interviews focused on the women's motivations to join the construction industry, what barriers they encountered both in their education and on the job, and what suggestions they have for ways to support women either interested in or already participating in the U.S. construction industry.
\end{abstract}

(c) 2020 The Authors. Published by Budapest University of Technology and Economics \& Diamond Congress Ltd Peer-review under responsibility of the Scientific Committee of the Creative Construction Conference 2020.

Keywords: construction management, human resources, personnel management, women

\section{Introduction}

America's persistent urban sprawl and rapidly aging infrastructure will continue to necessitate a competent construction industry to meet the nation's needs. For those that appreciate managing a project from the planning phase, through construction, and into building commissioning, construction management can be an excellent line of work. Due to the high median salary and low unemployment rate, the position of construction manager is ranked as the best construction job available, according to U.S. News \& World Report's Best Jobs Rankings (2017). Additionally, the career field of construction management is projected to grow 5\% from the years of 2014-2024 (BLS, 2015). Considering that women comprise $47 \%$ of the working population (DOL, 2011), it is shocking that women account for only $3 \%$ of construction managers (Stephenson, 2017). Why are there relatively so few women working in construction management? The research for this paper will identify social and economic factors that influence women's career opportunities and choices, identify ways to interest girls and women in construction management, and determine how employers can better support women already working as construction managers.

\section{Background}

\subsection{Social and economic factors influencing women's career decisions}

One of the major factors influencing many women's career decisions is the fact that women are often responsible for a greater share of the family and household responsibilities than men. Occupations that require odd or extended hours, like construction management, can be particularly challenging to women (Schieder and Gould, 2016). Work-life balance must be considered as 70\% of women with minor children living at home participate in the labor force (BLS, 2017). Economic considerations also influence women's career path. In 2016, the median annual salary for construction managers was $\$ 89,300$ (BLS, 2015). Since 
women tend to hold lower paying positions (Schieder and Gould, 2016), this relatively high salary could better support many working women and their families.

Girls and boys are often influenced by family members, teachers, and society in general to select toys that are gender normative. This results in girls often being steered towards dolls and people-oriented toys while boys are often encouraged to create structures with blocks, use power tools to build bird houses and other small projects, and help with household maintenance. This early experience working with their hands can contribute to boys' increased confidence which can affect their chosen fields of study in the future (Buschor, Berweger, Frei, Kappler, 2014). Traditional ideas of gender roles and norms influence women's career decisions and contribute to women being overrepresented in people-oriented careers such as healthcare, teaching, and sales (Lippa, Preston, Penner, 2014). Men are much more likely to be interested in and pursue things-oriented occupations, such as construction management (Lippa, Preston, Penner, 2014). Once these gender norms are imposed, often by the age of four, they are difficult to overcome and are even reinforced often by society (Islam, 2013).

\subsection{Creating interest in construction management among girls and women}

Educators and industry alike are placing a greater emphasis on exploring STEM (science, technology, engineering, and mathematics) subjects and promoting STEM careers than in the past. This should benefit recruitment in the field of construction management, as it involves working with new technologies and problem solving with engineering principles on every project. However, the STEM related areas are not emphasized and opportunities are squandered to introduce construction management to a new generation. Girls are particularly disadvantaged in this scenario as they are less likely to have hands-on experience with construction or building design than their male counterparts (Stephenson, 2017). It may seem obvious that girls benefit from being encouraged to pursue STEM interests in school. However, the timing of this encouragement is significant. Girls and female adolescents were much more likely to lose interest in STEM-related academic pursuits during the grades of $\mathrm{K}-12$, than they were in the transition between high school and higher education or during their time in college (Buschor, Berweger, Frei, Kappler, 2014), illustrating the need to promote STEM and construction management as early and often as possible to girls of school age.

The kind of STEM instruction girls receive is also critical. It is imperative to encourage hands-on, experiential learning environments including practical STEM-related experiments (Buschor, Berweger, Frei, Kappler, 2014). These experiments can contribute to an increased sense of excitement for STEM as well as greater confidence for the subjects. BASE (Broadening Access to Science Education) Camp is a summer camp in Fairfield, Connecticut for less privileged high school girls. The camp promotes STEM and incorporates an immersive learning experience, identification and discussion of STEM careers, and a guidance for college admission and applications (Phelan, Harding, Harper-Leatherman, 2017). The camp is for female students and run by female career women and graduate students currently in STEM fields. The BASE Camp has experienced great success and influenced $84 \%$ of the girls attending the camp to pursue STEM careers (Phelan, Harding, Harper-Leatherman, 2017). The camp's administrators attribute the participants' greater awareness and understanding of STEM subjects with increasing their confidence and excitement for STEM related occupations.

Finally, girls often expect to encounter negative experiences and feelings in STEM careers and expect to have lower positive experiences. Interestingly, the anticipation of negative experiences does not discourage girls from pursuing STEM careers as much as their anticipation of having fewer positive experiences (Schuster, Martiny, 2016). Therefore, it is crucial to introduce girls to role models in construction management who are willing to share their positive experiences in construction in order to inspire and excite girls about the field.

\subsection{Supporting women in construction management}

Employees of either gender want to feel physically safe on the construction site, as well as appreciated and respected (Barlow, 2016). This can be particularly elusive for women in construction management and there are steps the construction industry can take to better support women in construction. Isolation on the 
construction site can invite conflict and provide an opportunity for women to be harassed or assaulted. In an interview with National Women's Law Center (NWLC), Patricia Valoy, a civil engineering student working in construction management, described her experience with harassment on site as follows, "I worked on the site for a year until I decided the stress of constantly being harassed, belittled, and intimidated was not worth the effort. We need more women in the construction industry so we're no longer a rarity" (NWLC, 2014). In the spring 2017 issue of BuildingEnergy Magazine, Kate Stephenson has developed some "Tips for Retention" for construction companies looking for specific ways to better support women in construction. One such tip is to "End isolation on worksites by assigning women, trans and gender nonconforming people, especially those new to the trades, in pairs or more" (Stephenson, 2017).

Women, like men, want to feel that their work is appreciated and that they are respected by their peers. In fact, feeling underappreciated is a significant stressor for women in construction management (Bowen, Edwards, Lingard, Cattell, 2014). In the construction industry, women also tend to report higher stress levels than men (Bowen, Edwards, Lingard, Cattell, 2014).

One barrier that faces women in construction may arise from their own family or support system. Construction management is considered by some people to be a lower status occupation (Lippa, Preston, Penner, 2014). There is a culture around construction that tends be interpreted as "masculine" and often requires working long hours in physically challenging conditions (Ness, 2012). This can make it particularly challenging for women to find support from their families and friends when they express an interest in construction. It is critical to have women role models from construction management that can present a positive point of view for the industry and help improve the image and connotations associated with construction (Barlow, 2016). Respecting a work-life balance is also critically important to support women in construction management. Long term job satisfaction and commitment is greatly impacted by a company's understanding of and support for their employees' desire for work-life balance (Malone, Issa, 2013). Additionally, policies that allow flex time, working from home, or other family-friendly leave practices positively impacted an employee's level of job satisfaction (Malone, Issa, 2013).

\section{Research methodology}

Interviews were conducted with five (5) women, all of whom are either currently working in or have previously worked in construction management, to provide qualitative research to explore and understand the interviewees' experiences as women in construction management and to understand how these experiences may influence other women's interest in the construction industry.

A standardized, open-ended interview method will allow the interviewer to ask the same questions of all interviewees, but provide the interviewer flexibility to follow up with questions or ask for more information as necessary. Through personal telephone or in-person interviews, this paper will seek to illuminate why women who either are working or have worked as construction managers were motivated to join the construction industry, what barriers they have encountered both in their education and on the job, and identify methods to support women either interested in or already participating in the construction industry.

Interview questions:

1. Please describe your education and work experience in construction management.

2. Please describe when and how you became interested in construction management.

3. Were you encouraged, with the help of a family member, teacher, or mentor, to build things when you were a child (i.e. bird houses, anything with hand tools, etc)?

4. As applicable, when you were in school or early in your career, were you overtly encouraged or discouraged from interest in construction management, either from your family members, friends, professors, classmates, coworkers, management, etc? If so, please provide example(s).

5. In which geographic regions have you worked in construction management? Describe the difference in experiences and attitudes towards you in those areas, if any. 
6. How often have you taken positions with a different company? Did you feel that you had to transition to another company in order to get a raise and/or promotion?

7. How often are you aware of seeing women in construction management represented in training materials (i.e. videos, manuals, etc.), promotional materials (for university construction management programs, construction company advertising posters, brochures, etc.), and construction company websites? Please describe the impact this has on you, if any.

8. Please describe any steps your employer (or previous employers) could take to support women in the workplace (i.e. training, benefits, etc)?

9. Have you personally experienced harassment or assault (sexual or otherwise) while on the job? If so, please explain, to the extent you are comfortable sharing. How did you and your employer address the situation?

10. Do you participate in mentoring relationships, professional organizations for women in construction (i.e. National Association of Women in Construction (NAWIC), Professional Women in Construction (PWC), etc.), or apprenticeship programs? If so, how does this benefit you and/or other women in construction?

11. What advice would you offer to a woman interested in entering the field of construction management?

\section{Data analysis}

\subsection{Interviewee information}

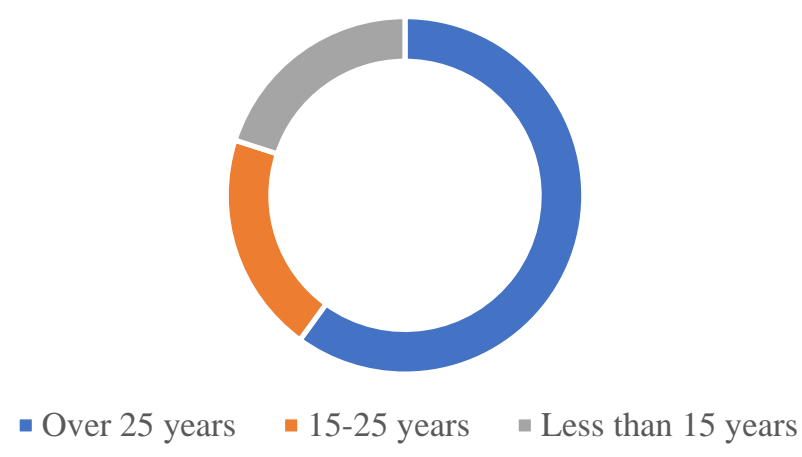

Figure 3: Interviewees' Years of Experience Working in Construction Management

The interviewees were carefully selected to represent a diverse set of experiences, with career length varying from thirteen to over thirty years of experience in the construction industry. Interestingly, none of the women interviewed for this paper were originally trained specifically in construction management. Two women have degrees in civil engineering, two women either are or were licensed interior designers, and one woman was trained as an architect. Most of their collective construction experience has been in the southeastern United States, though two women interviewed have managed construction overseas. A summary of each interviewee's educational and professional experience is listed below for context.

Ms. Catron-Cox graduated with a Bachelor's degree in Interior Design from the University of Tennessee in Knoxville, TN. She successfully completed the National Council for Interior Design Qualification (NCIDQ) exam, a professional exam which is required for registration and licensing. Her professional experience includes over 20 years of professional experience, with all but three of those years being in construction management positions. After college, she worked at an architectural and design firm in Knoxville, Tennessee for three years. She then became a consultant for a large medical imaging company, where she worked in construction management on site. She worked for Siemens doing consultant work as a full-time facility planner and designer. The first project she was primarily responsible for was a \$5-8 million addition. She was the "Internal Gatekeeper" for that project. Her career progressed with Siemens and she enjoyed the highly technical requirements and challenges of working with facilities which manufactured specialized 
medical equipment. At Siemens, she began as a facility planner, then facility manager, and eventually rose to Director of Facilities when Siemens was still a privately held facility. All told, she worked for Siemens for 13 years. After leaving Siemens, she worked for a church-related nonprofit in construction management, but after five and half years there, she became frustrated with the lack of training and opportunities in that position. She decided to pursue other opportunities. She currently works for CBRE real estate property management and is responsible for eighty to ninety BBT banks. She is ultimately responsible for the construction of these buildings.

Ms. Stanley has a B.S. in civil engineering from Georgia Southern University. She has worked for the U.S. Army Corps of Engineers for over 30 years, and most of that time was spent managing construction projects. She has worked on heavy civil projects, such as airport runways, as well as vertical construction. During her career, she has worked at Headquarters, with the Savannah and Mobile district offices, and now is working at the Huntsville Engineering and Support Center.

Ms. McDowell has a dual Bachelor of Science degree in mathematics and civil engineering from Georgia Tech. She has worked in construction management for 13 years. Ms. McDowell worked at a private construction consultant company for five years managing the construction on state government contracts. Afterwards, she began working for the federal government for eight years. She has worked for the Environmental Protection Agency and the U.S. Army Corps of Engineers.

Ms. Baldwin has a degree in interior design from the University of Alabama. She worked for nineteen years with an architectural and design firm in Huntsville, Alabama where she was responsible for many designbuild projects. After that, she spent eight years working as a Subject Matter Expert for design-build projects with a government contractor for projects on the Redstone Arsenal before finally taking an interior design position for the U.S. Army Corps of Engineers Huntsville Engineering and Support Center. Altogether, she has more than thirty years of experience, with most of that being in managing design-build construction projects.

Finally, the last interviewee is Ms. Beverly Gilliand-Parkes. Ms. Gilliand-Parkes earned a Bachelor of Architecture from Mississippi State University and worked in architecture for seven years after graduation. The architects she worked with recommended her for design-build construction projects. She soon left architecture and worked for Turner Universal Construction for ten years, first as an estimator and then she worked in their preconstruction department. She then went to work for Jessie Stutts, Inc., an electrical contractor in Huntsville, Alabama for approximately one year. After that, she worked at JH Partners Architecture-Interiors, a former architectural and design firm in Huntsville, Alabama. She worked there for approximately five years in the Construction Administration department where she was responsible for quality control on the firm's projects and acted as a liaison between the construction contractors and the architectural firm on design-build projects. She then worked for Dyson Construction for approximately two years and she currently works in government contracting for the federal government. Ms. Gilliand-Parkes has over twenty-five years of experience in architecture and construction management.

\subsection{Influences in childhood or school}

Many of the women interviewed for this research were interested in construction and building as children. While two of the women interviewed became interested only after their careers began. Three of the women, Sara Catron-Cox, Tamika McDowell, and Beverly Gilliand-Parkes, became interested in construction and building in their early childhood. Out of those three women, Ms. Gilliand-Parkes was actively discouraged from an interest in construction, because her father felt that it was inappropriate for his daughter. Her father supported her interest in architecture and drew a distinction between architecture and construction. She states that, to her father, "architecture was considered respectable." Out of the interviewed group, only Vicky Stanley was actively encouraged to help with maintenance and repairs around the house that would require the use of hand tools. As the oldest child in the family, Ms. Stanley was often included in work around the house and in the yard with her Dad. This is important because it may have contributed to a sense of confidence around this kind of equipment that she would not have had otherwise. She was not intimidated by work that required tools and equipment and that experience was unique of the women 
interviewed for this study. In fact, Ms. Catron-Cox was not allowed to use hand tools as a child. In college, she was the only female student in her surveying course. She got a chance to use hand tools for the first time in the class and expressed excitement for the opportunity.

Two of the women interviewed, Ms. Catron-Cox and Ms. Baldwin, studied interior design in college. This was encouraged by their family, although it is a more gender normative field of study. Ms. Stanley, Ms. McDowell, and Ms. Gilliand-Parkes, chose to pursue engineering, a dual mathematics and engineering degree, and architecture, respectively. Ms. McDowell shared her intentions to go into construction management upon graduation, and she had an aunt that would routinely discourage her from going into the construction industry. She states that, while she was in her third or fourth year of college, her aunt would tell her, "You will never be able to prosper in the construction industry." Ms. McDowell says that she believes her aunt meant that, as a female in the industry, it would always be an uphill struggle for her. If recruiting more women into the field of construction is the goal, these experiences are important to understand. Other women may face similar obstacles and challenges and respond by abandoning their interest in construction. Parents, other family members, and mentors can choose to support girls and young women when they show interest in construction, hand tools, and building.

\subsection{Experience with peers' attitudes while working in construction management}

Three of the five women interviewed described experiencing harassment on the construction site, while none of the women interviewed indicated that they were ever assaulted. Ms. Stanley describes whistling and cat calls being directed at her from men on site earlier in her career. Ms. Catron-Cox describes working with a man at the same position level as her who was "incredulous" towards her and she believes that was due in large part to her gender.

Ms. Gilliand-Parkes has worked on sites where men made crude comments about her body and began false rumors of her having affairs with other people on the site. She felt that some of the men on the team felt compelled to invent other reasons about why she would have her job, failing to believe that she was there because she was qualified and a valuable team member. Ms. Gilliand-Parkes also states that when it comes to personality on the jobsite, "You can't be 'the girl' and you can't be one of the guys. In a way, you just have to neuter yourself." She says that she feels that she must only be concerned with the work. She went on to state that her first job at a major construction company was "horrific" and that "Men didn't know how to handle it." In fact, the superintendent told her she "wouldn't get to prop (her) feet on the desk and eat bonbons" while she worked for him. She clarifies that this was never her intention. Ms. Gilliand-Parkes goes on to say that she often feels the need to prove that she "isn't the secretary on the jobsite."

\subsection{Seeing other women working in construction management}

When asked if they were aware of seeing women in construction management represented in training materials (i.e. videos, manuals, etc.), promotional materials (for university construction management programs, construction company advertising posters, brochures, etc.), and construction company websites, the women all responded that they had noticed that, in recent years, women were being represented in these training and promotional materials more often. However, none of the women interviewed indicated this had any personal impact on them.

Ms. Stanley even appeared in a U.S. Army Corps of Engineers training video and printed training materials for Construction Quality Management for the Redstone Arsenal. She says, "At HQ, they were doing a diversity recruitment initiative which included a photo shoot with a professional photographer." The effort resulted in a fully produced video and a full-page color advertisement in the 1990s. Many of the women indicated that they were determined and did not require this form of modeling to be encouraged. Ms. McDowell says, "I am strong willed. I don't have to see that represented for me to do it." Ms. Baldwin and Ms. Gilliand-Parkes indicated that they believed this increased visibility of women in construction management was due, at least in part, to an "EEO" initiative and not as a reliable reflection of the changing workforce in construction management. 
Additionally, none of the five women interviewed participate, or have ever participated, in professional organizations specifically for women in construction management such as the National Association of Women in Construction (NAWIC) or Professional Women in Construction (PWC). One of the women had even been encouraged by a colleague to participate in meetings at a similar organization and declined the invitation. Although none of the interviewees had attended any meetings, it was not a priority for them and they did not see enough benefit in these organizations to attend. However, organizations like this could provide some desired support and networking that could positively influence their careers.

\subsection{Steps employers could take to better support women in construction management}

Ms. Gilliand-Parkes believes that employers could make a better effort to build a more inclusive, respectful environment for women. She refers to the difficult superintendent that she worked for and notes that he never included her as part of their team. She says, "He never introduced me as Project Engineer over Quality Control." Instead, he would introduce her only by her name and omit her title. She believes it took a lot longer for her to build the trust and respect of the other team members because the superintendent signaled to them that he did not see her as respectable or part of the team.

Ms. McDowell also believes that it is imperative to have management that supports women in construction management. She says that laborers would often question her direction, until her management made it clear that they stood behind her. She was treated very differently from her male counterparts on site. She remembers that, on a jobsite in Florida, the men in the field would take direction from a male in Quality Assurance, who was not a degreed engineer, before they would take direction from her. She believes that was due to her gender. Ms. McDowell says that, in meetings on site for her work in North Carolina, she would typically be the only woman in the room. She says that she could "sit in a meeting, offer a suggestion, be ignored by everyone at the table, and then, fifteen minutes later, someone else at the table would have the same idea and everyone would get on board."

Ms. Baldwin speaks of "one good ol' boy experience" she had after she ended her employment with a government contractor. "It was a very male environment," she says. She felt that she could not fit in with the culture of the company. She said, "They could have given me the chance to manage projects, but they didn't want to let go of anything." She worked for the company for less than a year and described it as a "devastating experience" and one which she believes was gender-driven. Adequate and appropriate training opportunities were particularly important to two of the women interviewed. Ms. Catron-Cox states that the support for training was not there earlier in her career when she worked for a large healthcare corporation in the facilities division, but that she "didn't push it" with management. She then left the corporate world to work for a nonprofit for the value of the experience and to give back to her community. However, she eventually wanted more support for professional development and again found work in a for profit corporation. Ms. McDowell states, "In the majority of places I've worked, the management was really over supportive of training for me personally," Ms. McDowell says. When she worked in the private sector, her company encouraged her to take management training and it made her feel valued as an employee. Employers could either provide more opportunities for advancement within the company, or better communicate the existing opportunities for advancement to their female employees. Ms. Stanley says, "Women should be exposed to opportunities available to them (when they have) a civil engineering degree."

Ms. McDowell has typically felt that she needed to take a different position to get a promotion and/or earn a higher salary. She states that she has "only been promoted through movement, regardless of performance, workload, or responsibilities."

\subsection{Interviewees' advice for women interested in construction management}

The women interviewed for this research were asked what advice they would give to a woman interested in entering the field of construction management. Their advice was illuminating and it is a clear indication that there is more that could be done to support women in construction management. Their advice has been included below. 
Ms. Catron-Cox suggests that, early in their construction management career, women should "stand up boldly for what they need in salary requirements." She also states, "Go full steam ahead and don't look back. Don't let anything stop you. You can make a difference. Building those structures says a lot about our world. It's important to have knowledgeable people in construction management that care." She also stated that she recommends women in construction management stand up for themselves. She says to "Express yourself calmly but boldly." She also says, "Talk through things. Learn from each other. Remember that you're always learning. Work together as a team. What do you have to lose?" Ms. Stanley would encourage a woman interested in construction management to dress professionally and project a professional image. Ms. Stanley says, "You have to be smarter, as a woman, to get noticed and promoted. Be a strong personality. Be confident." She also cautioned, "Sometimes they're testing you because you're new, not because you're a woman."

Ms. McDowell offers the following advice, "Be ready to fight. It's an uphill struggle. You have to work twice as hard to be taken seriously. If that is where your passion lies, seek out support and guidance." Ms. McDowell states that women in construction management "have to be twice as smart and knowledgeable" as men in the industry. MS. Baldwin offers the following advice to women who are interested in the field of construction management: "Take no bull. Work with experienced contractors to build a wealth of knowledge. Get hands on." Ms. Gilliand-Parkes: "Go for it. There's no magic advice other than you got to jump in with both feet. Learn the job, do the job, and you'll eventually get the respect."

\section{Conclusions}

Construction management positions pay well, often offer opportunities to travel and work in different areas of the world, and can be greatly satisfying to someone that enjoys seeing a project literally rise from the ground. However, many of these benefits are not being adequately communicated to girls and young women that may have an interest in construction. The interest in construction and building is worthy of being encouraged, regardless of the gender of the person expressing the interest. Parents, teachers, mentors, and other people in position of influence in young people's lives should embrace and support this interest.

To attain gender parity in construction management, employers should focus on requiring a respectful, inclusive workplace culture with zero tolerance for harassment or assault for all employees. People in management positions have great influence in setting expectations for the rest of the team. When these people signal to the team that they respect each team member, regardless of gender, and expect others to as well, women directly benefit and they tend to notice and appreciate the effort.

Employers should also focus on providing quality training opportunities for continued professional development for women in construction management. Training ranked highly among the interviewees as important to their career. One interviewee even left a position in part because that employer was not supportive of adequate training. Employers could also better support and encourage participation in professional organizations specifically for women in construction management. Women not involved with such an organization could be missing valuable networking and resources for support. If women feel more supported, even outside of their employment, they may be more likely to remain in place and continue to contribute to that employer. Although the women interviewed tended to feel unaffected by seeing women in construction management modeled for them in training and promotional materials, the women interviewed acknowledged that they are seeing more women portrayed this way than ever before. The women interviewed may not be as susceptible to this type of modeling, but it may be beneficial to recruit more women in to the construction industry, specifically women who may not be as self-assured as the women interviewed.

Finally, the interviewees' advice for women considering a career in construction management clearly indicates that there are opportunities for improvement in the construction industry. The advice underscores that there are still challenges that women experience in construction. The cautionary advice is important for women to know, but it is also noteworthy that the women interviewed found construction management rewarding and fulfilling. They were all encouraging of other women to enter the construction 
industry. It is possible to create greater gender parity in construction management and an aging infrastructure is going to continue to require experienced, knowledgeable construction managers. Greater exposure to construction, building, and tools and equipment can increase confidence in girls and young women that may make them more inclined to consider construction management as a career. Once in the field, female construction managers may require specific support from employers to overcome genderspecific challenges. With a relatively high median salary and forecasted job availability, the field of construction management offers excellent opportunities to women interested in construction.

\section{References}

[1] Barlow, I., (2016, June). Attracting the Next Generation of Construction Workers. Construction Business Owner, Retrieved from http://www.constructionbusinessowner.com/management/workforce-management/june-2016-attracting-next-generation-constructionworkers

[2] Bieri Buschor, C., Berweger, S., Keck Frei, A., \& Kappler, C. (2014). Majoring in STEM-What Accounts for Women's Career Decision Making? A Mixed Methods Study. Journal of Educational Research, 107(3), 167-176. https://doi.org/10.1080/00220671.2013.788989.

[3] Bowen, P., Edwards, P., Lingard, H., Cattell, K. (2014). Workplace Stress, Stress Effects, and Coping Mechanisms in the Construction Industry. Journal of Construction Engineering and Management, 140(3). https://doi.org/10.1061/(ASCE)CO.1943-7862.0000807.

[4] Islam, C. (2013, November 10). Closing the STEM Gender Gap: Why Is It Important and What Can You Do to Help? Retrieved from http://www.huffingtonpost.com/celia-islam/closing-the-stem-gender-g_b_3779893.html

[5] Lippa, R. A., Preston, K., \& Penner, J. (2014). Women's Representation in 60 Occupations from 1972 to 2010: More Women in HighStatus Jobs, Few Women in Things-Oriented Jobs. PLoS ONE, 9(5), 1-8. https://doi.org/10.1371/journal.pone.0095960

[6] Malone, E. K., Issa, R. A. (2013). Predictive Models for Work-Life Balance and Organizational Commitment of Women in the U.S. Construction Industry. Journal of Construction Engineering \& Management, 140(3), 1. https://doi.org/10.1061/(ASCE)CO.19437862.0000809

[7] National Women's Law Center [NWLC]. (2014). Women in Construction: Still Breaking Ground. Retrieved from https://www.nwlc.org/wp-content/uploads/2015/08/final_nwlc_womeninconstruction_report.pdf

[8] Ness, K. (2012). Constructing Masculinity in the Building Trades: "Most Jobs in the Construction Industry Can Be Done by Women." Gender, Work \& Organization, 19(6), 654-676. https://doi.org/10.1111/j.1468-0432.2010.00551.x.

[9] Occupational Safety \& Health Administration [OSHA]. (2017). Women in Construction - Home. Retrieved from https://www.osha.gov/doc/topics/women/index.html

[10] Occupational Safety \& Health Administration [OSHA]. (2017). Women in Construction - Personal Protective Equipment. Retrieved from https://www.osha.gov/doc/topics/women/ppe.html

[11] Occupational Safety \& Health Administration [OSHA]. (2017). Women in Construction - Sanitary Facilities. Retrieved from https://www.osha.gov/doc/topics/women/facilities.html

[12] Phelan, S. A., Harding, S. M., \& Harper-Leatherman, A. S. (2017). BASE (Broadening Access to Science Education): A Research and Mentoring Focused Summer STEM Camp Serving Underrepresented High School Girls. Journal of STEM Education: Innovations \& Research, 18(1), 65-72.

[13] Poirier, L. (2016). Industry Need for Women Set To Spark “Transformation.” ENR: Engineering News-Record, $277(6), 16-16$.

[14] Schieder, J., Gould, E. (2016). "Women's work" and the gender pay gap: How discrimination, societal norms, and other forces affect women's occupational choices-and their pay. Economic Policy Institute. Retrieved from http://www.epi.org/publication/womens-workand-the-gender-pay-gap-how-discrimination-societal-norms-and-other-forces-affect-womens-occupational-choices-and-their-pay/

[15] Schuster, C., \& Martiny, S. (2017). Not Feeling Good in STEM: Effects of Stereotype Activation and Anticipated Effect on Women's Career Aspirations. Sex Roles, 76(1/2), 40-55. https://doi.org/10.1007/s11199-016-0665-3.

[16] Stephenson, K., (2017, March). Breaking Down Gender Bias in the Construction Industry. BuildingEnergy Magazine, 36(1), Retrieved from http://www.nxtbook.com/naylor/ENEB/ENEB0117/index.php

[17] U.S. Bureau of Labor Statistics [BLS]. (2015). Construction Managers: Occupational Outlook Handbook. Retrieved from https://www.bls.gov/ooh/management/construction-managers.htm

[18] U.S. Bureau of Labor Statistics [BLS]. (2017). Employment Characteristics of Families - 2016. Retrieved from https://www.bls.gov/news.release/famee.nr0.htm

[19] U.S. Department of Labor [DOL]. (2011). Women's Bureau - Quick Facts on Women in the Labor Force in 2010. Retrieved from https://www.dol.gov/wb/factsheets/qf-laborforce-10.htm

[20] U.S. News \& World Report. (2017). Construction Manager Ranks among Best Jobs of 2017. Retrieved from http://money.usnews.com/careers/best-jobs/construction-manager 